Article

\title{
Deforestation and Forest Degradation as an Environmental Behavior: Unpacking Realities Shaping Community Actions
}

\author{
Lalisa A. Duguma ${ }^{1, *}$, Joanes Atela ${ }^{2}$, Peter A. Minang ${ }^{1}$, Alemayehu N. Ayana ${ }^{3}$, \\ Belachew Gizachew ${ }^{4}$, Judith M. Nzyoka ${ }^{1}$ and Florence Bernard ${ }^{1}$ \\ 1 World Agroforestry Centre \& ASB Partnership for the Tropical Forest Margins, UN Avenue, Gigiri, \\ P.O. Box 30677, Nairobi 00100, Kenya; p.minang@cgiar.org (P.A.M.); j.nzyoka@cgiar.org (J.M.N.); \\ f.bernard@cgiar.org (F.B.) \\ 2 African Centre for Technology Studies ICIPE, Duduville Campus, Kasarani, Nairobi P.O. Box 45917, \\ Nairobi 00100, Kenya; J.Atela@acts-net.org \\ 3 Ethiopian Environment and Forest Research Institute, P.O. Box 24536, Addis Ababa 1000, Ethiopia; \\ alemayehunayana@gmail.com \\ 4 Norwegian Institute of Bioeconomy Research (NIBIO), Høgskoleveien 8, NO-1431 Ås, Norway; \\ belachew.gizachew@nibio.no \\ * Correspondence: 1.a.duguma@cgiar.org; Tel.: +254-(020)-722-4578; Fax: +254-(020)-722-4100
}

Received: 23 December 2018; Accepted: 26 January 2019; Published: 29 January 2019

\begin{abstract}
Deforestation and forest degradation (D\&D) in the tropics have continued unabated and are posing serious threats to forests and the livelihoods of those who depend on forests and forest resources. Smallholder farmers are often implicated in scientific literature and policy documents as important agents of D\&D. However, there is scanty information on why smallholders exploit forests and what the key drivers are. We employed behavioral sciences approaches that capture contextual factors, attitudinal factors, and routine practices that shape decisions by smallholder farmers. Data was collected using household surveys and focus group discussions in two case study forests-Menagesha Suba Forest in Ethiopia and Maasai Mau Forest in Kenya. Our findings indicate that factors that forced farmers to engage in D\&D were largely contextual, i.e., sociodemographic, production factors constraint, as well as policies and governance issues with some influences of routine practices such as wood extraction for fuelwood and construction. Those factors can be broadly aggregated as necessity-driven, market-driven, and governance-driven. In the forests studied, D\&D are largely due to necessity needs and governance challenges. Though most factors are intrinsic to smallholders' context, the extent and impact on D\&D were largely aggravated by factors outside the forest landscape. Therefore, policy efforts to reduce D\&D should carefully scrutinize the context, the factors, and the associated enablers to reduce forest losses under varying socioeconomic, biophysical, and resource governance conditions.
\end{abstract}

Keywords: behavior; deforestation; drivers; forest degradation; livelihoods

\section{Introduction}

Forests provide multiple ecosystem services spanning from local livelihoods and socioeconomic development related goods and services such as food, wood, and water to the global ecological and economic services, such as ecosystem functioning, biological diversity, carbon dynamics, and climate. However, deforestation and forest degradation (D\&D) are causing a significant reduction in the provisioning of valuable ecosystem goods and services from forests in developing countries [1] in the tropics currently poses the greatest threat to the forest ecosystem and the goods and services 
they provide. On the other hand, efforts to save forests have attracted enormous international attention. The United Nations Millennium Development Goals [2] and the United Nations Framework Convention on Climate Change-UNFCCC - have emphasized forest conservation as part of achieving sustainable development. These efforts have been reinforced through new global development agendas such as the Sustainable Development Goals (Goal 15) and the Aichi targets [3].

A global policy for reducing emissions from deforestation, forest degradation, and other forest management activities (REDD+) is designed to mitigate climate change and achieve sustainable development through forestry activities [4]. REDD+ was formally recognized as part of the UNFCCC climate regimes in 2007 during the UNFCCC 13th Conference of Parties (COP). It is drawn from scientific evidence that shows deforestation causes $17-20 \%$ of global greenhouse gases (GHG) emissions [5,6]. Reducing deforestation could cost-effectively support sustainable forest conservation and mitigate climate change [7,8]. To enhance the effectiveness of such new policies, the 2012 Earth Summit emphasized the need for transformative policies to enhance effectiveness of such emerging schemes [9].

Transformative policies require a systemic understanding of the context of deforestation in order to identify strategic interventions [10]. Therefore, to effectively address deforestation through REDD+, it is important to identify key drivers of deforestation and forest degradation. In developing countries, deforestation and forest degradation debates attribute forest losses to the interactions between multiple factors on livelihoods and development. These debates have informed the focus of REDD+ in these countries where most tropical forests support livelihoods of resource poor communities and development initiatives [1,5,11]. According to the UN-REDD framework [12], half of deforestation in tropical areas is caused by livelihood activities such as shifting cultivation by resource poor communities and smallholders. Africa is home to the largest proportion of forest dependent subsistence smallholder farmers in the world [13]. Hashmiu [14] in Ghana and Dzingirai [15] in Zimbabwe claim that smallholder-driven deforestation is responsible for hunger and poverty in targeted areas and thus reducing deforestation and new forestry schemes will help alleviate poverty and boost food security. Some studies, however, acknowledge that the D\&D in smallholder context is complex yet sometimes oversimplified to livelihood needs. These studies highlight that broader factors, e.g., illegal logging and externally driven markets [16], nest into the peasantry-deforestation nexus [1]. Poor understanding of this complex interaction may only continue to put more blame on these communities while ignoring the fundamental drivers to D\&D that ought to be addressed.

To date, most assessments of D\&D ignored the behavioral aspects that play a critical role in how farmers make the decisions to engage in D\&D and what factors drive this behavior. Drawing on two case studies in eastern Africa, we explored the contextual as well as attitudinal and habit factors driving D\&D by smallholder forest dependent communities. Emphasis was placed on identifying the typologies of factors that drive smallholders to D\&D from an environmental behavior point of view. Lastly, we suggest selected strategies for minimizing D\&D within the context of the smallholder farmers.

\section{Conceptual Framing to Explain D\&D as an Environmental Behavior}

To contextualize smallholder-driven D\&D, we used the attribution theory. It was originally designed in social psychology to explain how and why people form an opinion or perception about a particular event, resource or observation [17]. The theory helps in judging human understanding, decision-making, and actions. A particular action can be judged on whether a behavior was caused by internal or external reasons, i.e., by the actor or by something outside the actor [18]. In explaining D\&D, the attribution theory will form the basis for explaining the events, processes, or decisions to which the smallholder-related D\&D problems could be attributed. Accordingly, for instance, smallholder-driven D\&D could be caused by livelihood needs but could also be a result of external pressures such as land deprivation or markets for forest products. Both external and internal pressures affect the welfare of the actors concerned [19]. 
Steg and Vlek [20] state that environmental behavior is driven by any or combination of three key factors: motivational factors (i.e., perceived costs and benefits, moral, and normative concerns and affect), contextual factors, and habitual behavior. Stern [21] gives a more elaborate view of this by identifying four causal variables for a given environmental behavior: attitudinal factors; contextual forces; personal capabilities; and habit or routine behaviors (Figure 1). Within the framing of the current study, we considered personal capacity as not seriously important, since every household depends on forest products irrespective of their capacity. Livelihood is a key part of the contextual factors driving D\&D.

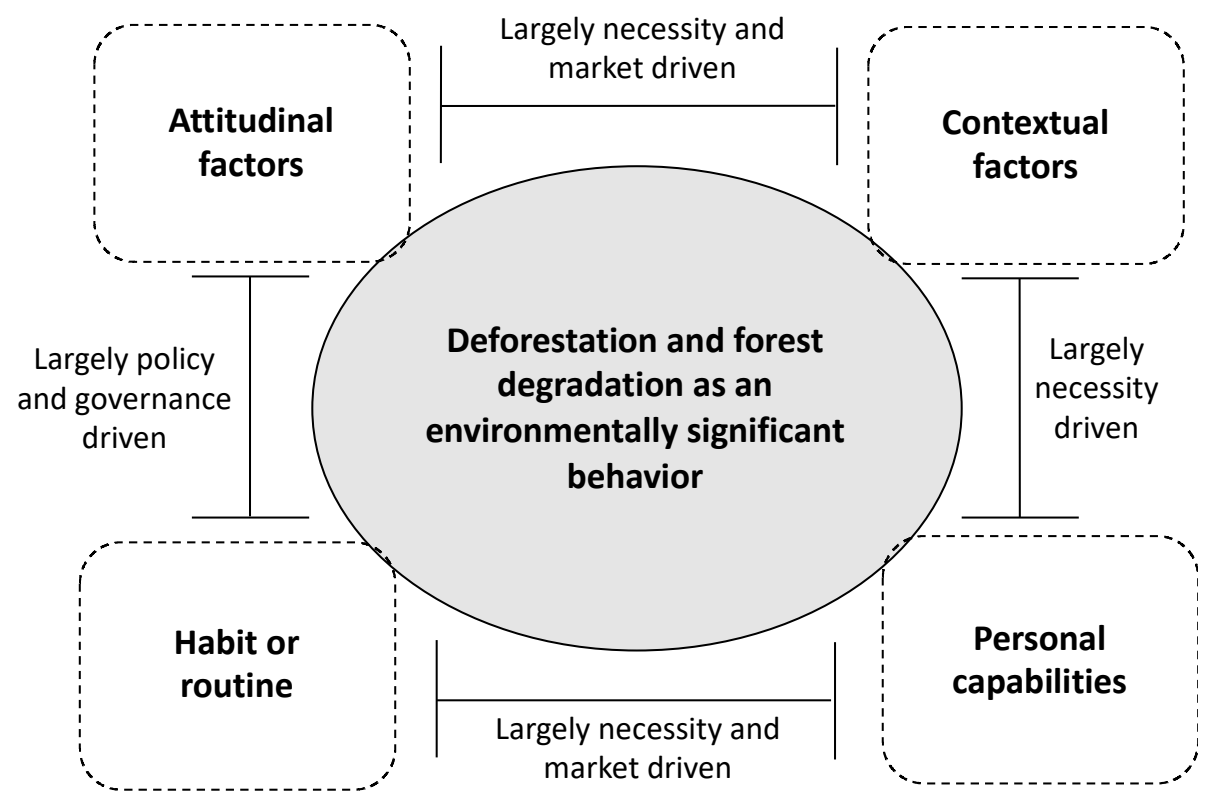

Figure 1. Conceptual framing of the aspects of deforestation and forest degradation (D\&D) as an environmental behavior.

To achieve pro-environmental behavior, Steg and Vlek [20] proposed two key strategies that target the factors that influence environmental behaviors. (1) Informational strategies that focus on changing the perceptions, norms, motivations and knowledge and (2) structural strategies that target changing the context in which decisions about a given environmental behaviour are made. This study looks through these two lenses to identify what could possibly help to minimize factors aggravating D\&D.

\section{Materials and Methods}

\subsection{Research Approach}

We adopted the case study research approach [22,23], to get detailed insights into D\&D. The approach helps in integrating new insights into already existing body of knowledge, and particularly improves on existing studies that have tackled drivers of D\&D from broader scales, i.e., national, regional, or biome (global) levels [24-26]. Such broadly framed investigations may not capture the contextual heterogeneity within which D\&D occur at local levels. Besides, in different contexts the drivers of D\&D often vary on a case-by-case basis. Thus, there is need to look at the drivers in a context specific lens. Our study is mainly concerned with factors driving D\&D in the smallholders' context and this can adequately be informed by contextual case study investigations.

\subsection{Case Study Forests}

We selected two forests-Menagesha Suba Forest (MSF) in Ethiopia and the Maasai Mau Forest (MMF) in Kenya (Figure 2). The two forests were selected because both have been severely affected by D\&D in the last few decades and thus may help to understand the underlying factors that drive D\&D 
at local levels. MSF is located about $30 \mathrm{~km}$ west of Addis Ababa-the capital city of Ethiopia-and is also surrounded by three fast growing towns (Sebetta, Holetta, and Menagesha). The forest area decreased from 9557 ha in the 1980s to 3530 ha by 2006 [27], shrinking by $23 \%$. MMF is located in Narok County, Kenya, $150 \mathrm{~km}$ from Nairobi, the capital city of Kenya. It is one of the forest blocs that make up the Mau Forest Complex, the biggest remaining natural forest in Kenya spanning over 400,000ha [28]. The MMF block experienced a significant decline in forest area: from 46,278 ha in 1973 to $\sim 41,574$ ha in 2005 [28].

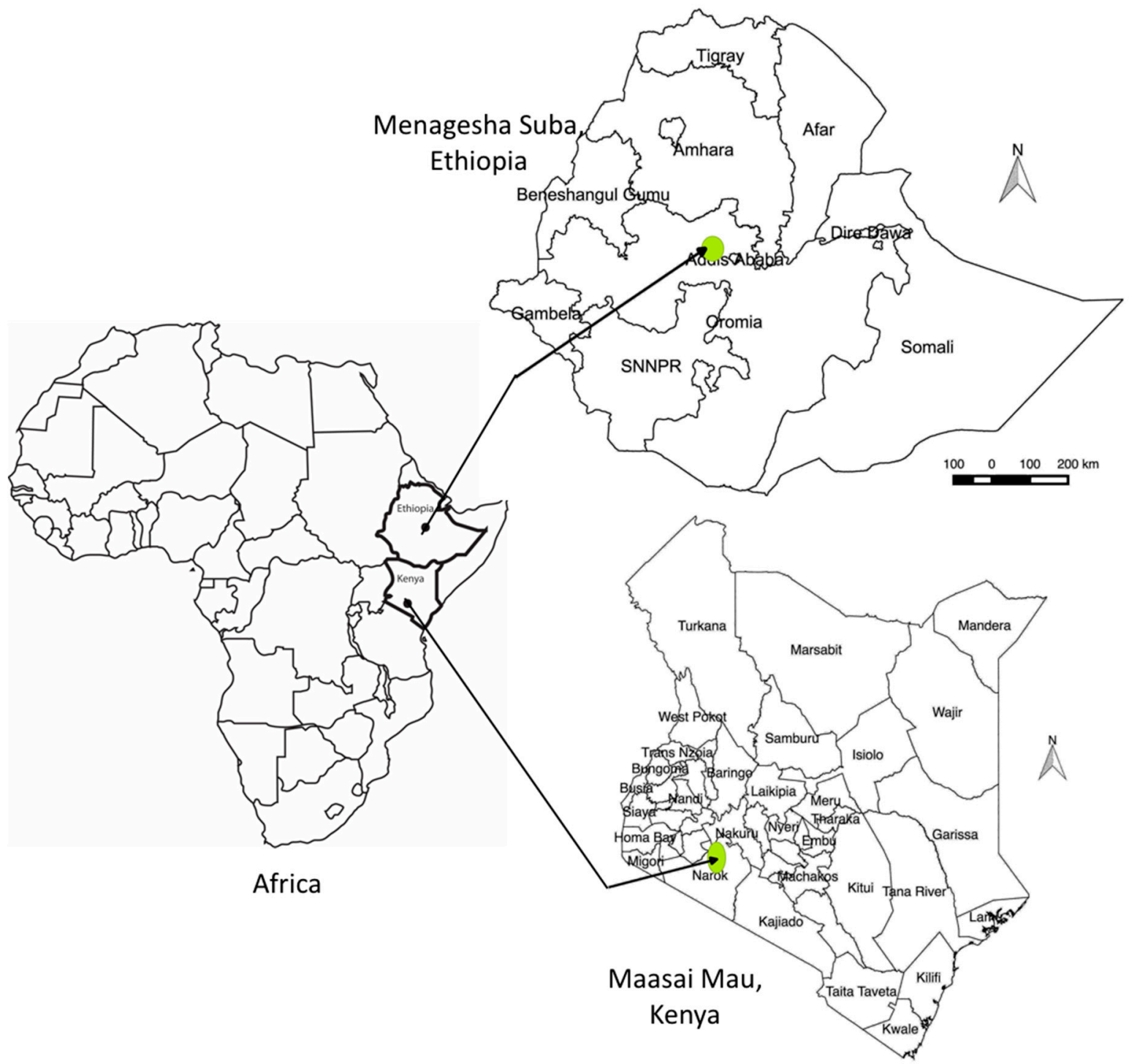

Figure 2. Location of the two case study forests, Menagasha Suba Forest, Ethiopia, and Masaai Mau forest, Kenya.

\subsection{Data Sources and Analysis}

We conducted household survey consisting of questionnaires on how smallholders perceive the forest in terms of its value, what their activities are, and which factors lead them to D\&D, why there are several cases of illegal exploitations and what the root causes to the problems are. The survey in Menagesha Suba area covered 397 households in and outside the forest margin, while in Maasai Mau 100 households were interviewed. In addition, for an in-depth probing of issues relating to the forest management and community interactions, we conducted six focus group discussions-one in Menagesha Suba with 12 participants and five in Maasai Mau. The forest management officers in MSF 
and Kenya Forest Service guards in MMF were interviewed to explore their views and perceptions about the local community. Spatial and biophysical data on forest dynamics and policy-related issues were collected through literature review of both published and unpublished documents.

Data and information on socioeconomic, demographic, policies and governance, agricultural and forest related interventions, and other production factors as well as household and community collective behaviors were collected. Different sources of information helped to triangulate the results of the survey, and also to understand the complex network of drivers that operate both from within and outside the landscape. Descriptive statistics was used as the main data analysis method.

\section{Results}

\subsection{Factors Driving DED in Menagesha Suba Forest (MSF), Ethiopia}

In MSF, contextual factors dominated as the main forces behind D\&D. There are also some attitudinal and habit related factors that played a role in forest destruction. Most of these forces are necessity- and market-driven by nature, though there is also some influence from governance related matters.

\subsubsection{Contextual Factors Driving D\&D in MSF, Ethiopia}

Three major categories of factors affecting forest cover in MSF were identified: (1) sociodemographic factors; (2) production factor constraints; and (3) policies and resources governance issues. These factors operate at different paces, in different combinations and in different conditions even within a specific location.

Sociodemographic factors: Among the key sociodemographic factors affecting D\&D was the rising demand for forest products due to increasing population in the rural, urban, and peri-urban communities. The population in close by towns such as Holetta and Sebeta increased by $29 \%$ and 203\%, respectively, between 2005 and 2015. In the same period, the population in Addis Aababa increased by $\sim 13 \%$. The population in Addis Ababa city increased by almost $2 \%$ every year between 2014 and 2017. Projections done by Central Statistical Authority (CSA) indicate that the population in Sebeta and Holetta are likely to increase by 5\% annually between 2014 and 2017 [29]. The observed increase is attributed to the rising population of the resident communities and the migration from other regions to urban and peri-urban areas adjacent to the forest. For instance, Feyissa et al. [30] reported a significant expansion of settlement area by 122\%—from 4752 ha in 1984 to 10,563 ha in 2006 within the Holetta watershed, which comprises MSF. Most of these increased residential areas still rely on wood for construction and energy, most of which is supplied by MSF.

The increasing wood demand was also exacerbated by the limited access to alternative energy materials (e.g., electricity, solar panels, etc.) and alternative nonwood construction materials (e.g., steel, concretes, etc.). These limitations force the communities in the landscape to largely rely on surrounding forests both for energy and construction. Our survey results showed that $61 \%$ of the rural households rely on the forest as the main source of wood and other forest products. For instance, over $99 \%$ of the 16,545 rural housing units standing in 2007 in Welmera district, where Menagesha forest is located, was built of wood [31]. Duguma and Hager [32] estimated that at least 39\% of wood required for constructing rural housing units originated from natural forests. Computation from the national census data [31] also revealed that $99 \%$ and $27 \%$ of the households in the district rely on fuelwood and charcoal as main cooking energy, respectively. Dependence on multiple energy sources are common due to insufficient supply potential.

The urban and peri-urban areas are also experiencing a significant boom in residential and commercial buildings largely influenced by the increasing population in the areas. For instance, Sebetta town experienced a greater than $300 \%$ increase in housing unit construction, most of which were wooden wall and thus demanding wood from forests and or woodlots. Sharp increases were also observed in Addis Ababa and Holetta (Table 1). The expansion of urban and peri-urban areas to date 
is not proportional with the infrastructural demands of the increasing population and hence increasing the pressure on forests for extracting construction wood and fuelwood. This agrees well with other studies such as DeFries et al. [33] who elaborated on similar impacts of urbanization.

Table 1. Wood dependency in urban and peri-urban areas surrounding Menagesha Suba Forest (MSF).

\begin{tabular}{cccccc}
\hline \multirow{2}{*}{$\begin{array}{c}\text { Urban Areas } \\
\text { Neighboring the } \\
\text { Forest }\end{array}$} & \multicolumn{2}{c}{$\begin{array}{c}\text { Construction Wood Needs } \\
\text { Number of Additional } \\
\text { Housing Units Built } \\
\text { between 1994 and 2007 }\end{array}$} & $\begin{array}{c}\text { Proportion of Wooden Wall } \\
\text { Houses out of the Total } \\
\text { Housing Units (\%) }\end{array}$ & $\begin{array}{c}\text { Major Energy Sources for Cooking } \\
\text { Energy (\% of Households) }\end{array}$ \\
\hline Addis Ababa city & $254,243(68 \%)$ & 77.15 & 68 & 52 & 35 \\
Holetta town & $3015(82 \%)$ & 95.90 & 94 & 46 & 0 \\
Sebetta town & $8749(312 \%)$ & 95.59 & 78 & 74 & 17 \\
\hline
\end{tabular}

${ }^{1}$ Note that due to dependence on multiple sources of energy the percentage sum for the energy sources exceeds $100 \%{ }^{2}$ Numbers in the bracket show percentage increases in the indicated period.

Demands from the growing nearby urban and peri-urban areas usually increase wood products marketing opportunity and hence motivating local communities to engage in extracting wood from forests for sell. We found that $41 \%$ of the studied households collect and sell at least one forest product. Fuelwood and charcoal were the most commonly extracted and marketed wood products with approximately a third of the households engaged fuelwood collection and charcoal making. Duguma et al. [27] also reported that about $23 \mathrm{~m}^{3}$ of charcoal goes to close-by towns every market day recurring twice every week. Only $9 \%$ of the studied households were engaged in extracting and marketing of timber and construction wood. Documentation from the forest management office indicate that between 2001 and 2004, close to 1280 sacks of charcoal and 951 planks and poles of indigenous trees extracted from MSF were confiscated by forest guards. During the same period, around 286 people were arrested while transporting charcoal produced in the forest. Thus, the market opportunity created by the surrounding urban and peri-urban communities played a detrimental role since such illegal extraction is often unregulated.

Production factors constraints: Shortage of land for agriculture and settlements and poor land productivity are two major production factors at play in relation to D\&D. The land shortage was caused by rapid population growth in the area due to increasing number of new families from the youth population and new settlers coming to the area. Farmers in the area confirmed that per household land holding is declining, e.g., their grandfathers had $\sim 0.68$ ha more land than the respondents' fathers. The only mitigation strategy farmers adopted for the land shortage was to clear the forests close to the boundary. Furthermore, the poor productivity of agricultural lands due to declining soil fertility drives smallholders to venture into the forests as new farmlands or for alternative sources of livelihoods. Fifty-six per cent $(56 \%)$ of the respondents indicated that poor soil fertility constrains the production of enough food for the family. As Dercon et al. [34] indicated, such farmers can hardly afford inputs such as inorganic fertilizers to enrich their soils. Locally available alternatives such as compost were constrained by competing uses of crop residues for cooking and heating [35].

Policies and resource governance factors: The current state of MSF has largely been shaped by history that spans centuries back. Along the (political) power transitions in the country, MSF was subjected to several policies that also influenced how local communities benefited from it. Historical accounts suggest that MSF used to be an intact natural forest till the century but the large part was clear-cut and replanted with Juniperus procera. After the century, imperial regulations helped to protect the forest. In 1900, the then administration deployed guards to protect the forest. Until 1954, MSF was logged intensively. After the 1950s, the forest was put under a full protection scheme with no logging. In 1984, the first official demarcation of the forest boundary, by the socialist Derg ${ }^{1}$ regime resulted in

1 Derg stands for the communist military regime that ruled Ethiopia from 1974 to 1991. 
the eviction of hundreds of households from the forest-demarcated zone. Approximately $67 \%$ of the 381 households we interviewed were relocated to close by areas outside the forest. The relocation was done without (1) consultation and prior consent, (2) due consideration of the farmers' needs, and (3) considering the implications of the eviction on the lives of the farmers. Relocation intensified illegal exploitation of the forest.

With the changing forest management approaches, the community was left out and began claiming the right to use the forest through all possible means, though no legitimate response was given to their queries. Such forest management regime, which gave no attention to the needs of local communities, pushed some of the surrounding communities to have negative impressions about the forest management officers. An expression of one of the evicted farmers captures the reality very well.

"Where shall we go? What do we have left? Our animals have nothing to graze on and we have nothing to eat. Our land is planted with trees. Here, we are left on a rocky slope without soil and grass for the livestock." A respondent's opinion (Translated from Afan Oromo language).

Besides the eviction, the use rights of the local communities to the forest were also restricted. For instance, fuelwood, construction materials and grazing were permitted before the socialist regime demarcated the forest area. The demarcation effectively restricted smallholders from accessing most forest goods and services. While farmers could access certain forest products by seeking permission from forest management offices, this was complicated by bureaucratic procedures. Fuelwood collection is only permitted for women and children under strict regulation that they should not use axe in the forest. Anyone bypassing these regulations was arrested and prosecuted. To the local community, such intense use right restriction was seen as unnecessary and unwelcoming. The exclusion of the local communities' use rights has extended to the present day, which created strong sense of hostility between surrounding communities and government forest services.

\subsubsection{Attitudinal and Habit Factors}

Approximately $90 \%$ of the interviewed people appreciate the importance and the existence of the forest and expressed their desire to conserve it. However, we noted that $10 \%$ of the respondents did not appreciate the existence of the forest because they lost their land or were evicted from their land due to forest area demarcation. None of the farmers were sufficiently compensated when they were relocated. They felt neglected by the respective governments to compensate them for property lost due to the eviction.

The relocation created negative views and drove farmers to illegally and exploitatively extract forest products at any possible opportunity. Indeed, the process degenerated into intense conflicts and court proceedings. The intensity of this problem was what led the government to assign a specific lawyer as a resident staff for the MSF. The following quote taken from the interview we did with the lawyer also highlights the extent of the problem clearly.

"Almost every day, we deal with somebody charged with illegal exploitation of the forest. Even those who were convicted in court due to their wrong doings, after finishing their jail term, would come back and engage in illegal exploitation." A respondent's opinion (Translated from Amharic language).

Besides the factors discussed earlier, such forest governance schemes that marginalize the local communities through chain of management processes have played a crucial role in exacerbating the D\&D problems.

The confrontation between the local communities and the MSF management continued to escalate due to the routine fuelwood and construction wood extraction by residents from the forests. The communities were doing this for centuries and only had limited options of sourcing such materials since they relied on the forest for generations. The MSF management tried to embrace this need by allowing women and children to collect fuelwood from the forest after getting permission from the forest guards. Besides, the community did not even understand why the restriction was imposed in a forest which they used to freely access and even participate in its management. 


\subsection{Factors Driving DED in Maasai Mau Forest (MMF), Kenya}

MMF is influenced by multiple factors that altogether led to severe decline in forest cover. In MMF, the most important factors are related to contextual factors particularly governance failures. Necessity-driven attributes are also present but not as a major factor.

\subsubsection{Contextual Factors Driving D\&D in MMF, Kenya}

Four factors were identified as underlying drivers of forest loss: irregular and unclear land allocation practices (group ranches expansion); market forces (demand for timber, charcoal, and other non-timber forest products); subsistence needs (creation of new farms, fuelwood collection, and non-timber forest products gathering generally for livelihoods); and weak policy instruments.

Irregular and unclear land allocation practices: The expansion of group ranches in MMF area is the major factor for the loss of $\sim 14,103$ ha forest [28] which is close to $44 \%$ of forest loss in the area between 1973 and 2005. The ranches have expanded beyond their officially designated (registered) areas into the forest and areas surrounding the forest. In principle, Maasai Mau is a trust land (a land which is owned by the community for communal uses) [36]. However, despite being a trust land, several people claimed to have legal title deeds to parcels in the areas designated as forest, thereby reinforcing restrictions on access and utility by members of the community. According to the Kenyan law, once a piece of land is issued a title deed it is no more a trust land but privately owned. According to Kenya's National Environment Management Authority [37], individually owned parcels within the MMF were illegally allocated. Yet to date, settlements on trust land within the MMF cover 23,301 ha [37] with various communal sections such as group ranches being excised for the purposes of establishing settlement (unpublished thesis) against the initial plans and rights of the forest/local/indigenous people.

Sociodemographic pressures: Several sociodemographic factors are at play in the MMF area, which can be summarized as (1) clearing forests for farmland expansion (subsistence needs), (2) demand for forest products with the rising rural population, (3) the market factor that arises due to increasing demand from urban and peri-urban areas (e.g., charcoal production and logging of indigenous trees). These demographic pressures coupled with other shocks such as poverty, climate change drives over-dependence and subsequent overexploitation of forests for livelihoods and income. For instance, with the growing human population (due to the new settlements) in Maasai Mau area the importance of forests for the livelihood of the local communities is strongly increasing. For instance, the population of Narok County is now four-fold of its 1970s size according to population figures for 2009 [38,39]. In Bomet, a County adjacent to MMF, the 2009 population size was 3.6 times that of 1970s. According to the Kenyan government [40], 99 and 75\% of the households in Narok and Bomet counties, respectively, rely on fuelwood while the use of electricity is limited to approximately 15 and $7.7 \%$ of the households, respectively. With intense population growth and strong reliance on forest products for energy, the market for forest products is expected to be very high. Such rapid population growth around MMF may result in forest encroachment for settlements as well as for market as it may increase demand for land for food production, firewood for domestic energy use, and or construction materials such as poles and grasses, which often are harvested from forests. Smallholders around MMF acknowledge the importance of the forest for their livelihood. We found that $60 \%$ of the households rated forest goods and services as important for their daily livelihood. These benefits included water source $(93 \%)$, building material $(88 \%)$, habitat for wildlife $(82 \%)$, and grazing $(78 \%)$. Other benefits from the forest include source for fuelwood $(74 \%)$, charcoal $(68 \%)$, herbal medicines $(66 \%)$, tourism $(65 \%)$, farming area $(64 \%)$, and forage for livestock $(63 \%)$. Charcoal and firewood serve as sources of energy for $\sim 99 \%$ of the rural population. We found that the demand for these products was higher during dry seasons revealing the importance of the forest in coping to potential changes in environmental conditions. Narok and Bomet towns, which are vastly expanding in recent years, have become the main demand sources for charcoal and other non-timber forest products originating from this forest. 
Institutional failures: Institutional failure has played a major role in fueling and complementing D\&D drivers in MMF. The MMF has gone through various management strategies, most of which have fueled internal and external D\&D in the forest. Initial forest management approaches such as shifting cultivation in the 1970s and the Shamba system in the 1980s were gradually abolished. Both shifting cultivation and the Shamba system aimed to integrate subsistence farmers into forest management by allowing them to cultivate crops in the forests and plant and care for the trees before moving to other forest sections [41]. In the context of a rising population, the postcolonial authorities, especially in the land sector used peasantry agriculture as spaces for politically driven allocation of forest lands. The authorities allocated gazetted forests as part of settling landless peasants [42]. In the era of multiparty democracy in Kenya and associated competitive electoral politics, resettlements in forest areas were executed mainly as part of gaining electoral advantage. Sections of MMF were also allocated to loyal political and private sector actors for commercial agriculture such as tea plantations [42]. Additionally, corrupt practices among the forestry and local governments extended official resettlement boundaries allocating, to themselves, extra forest areas [42]. As a result, in the period between 1972 and 1990 Kenya recorded the highest natural forest losses [43].

Despite the proliferation of illegal logging from outside forces, rehabilitation policies have often targeted smallholders. The policies emphasized eviction of illegal settlers and taking back land possessed illegally by the ranches. Thousands of smallholders were moved out of the forest. Despite the eviction threats, the community expressed their enthusiasm in forest conservation activities as any forest destruction leads to the decline in the provisioning of these goods and services, which they needed daily.

In recent times, however, emerging forest decentralization policies such as participatory forest management [44] are expected to empower smallholders to sustainably utilize forests but even so, the external pressures emanating from illegal logging remain unresolved. The Kenya Forest Act of 2005 particularly legalizes community forest associations as a mode of governance within which local communities can participate and benefit from integrated forest management initiatives $[45,46]$.

\subsubsection{Attitudinal and Habit Factors Driving D\&D in MMF, Kenya}

Attitudinal factors driving D\&D in MMF have been mostly governance-driven. Indeed, MMF is located in one of the major water towers of Kenya. With the emphasis put on water towers in Kenya, the government wants to make sure that the forest is managed properly. Therefore, this triggered contested rights of use and contested ownership issues. The mass eviction that happened in MMF is largely due to the strong recognition of the importance of the water tower and the fact that forest managers think community interference with the forest affects forest management. However, for the local communities, it is their home that their forefathers and children lived in for centuries. Besides, MMF was the main source of fuelwood, construction wood, non-timber forest products, grazing lands, etc. No other sources of these materials exist in the area. Charcoal marketing was among the key factors that affected the forest. This is largely driven by the needs arising from urban and peri-urban communities residing close to the forest.

\section{Discussion}

\subsection{Key Aspects of Factors Behind Smallholder-Driven DED}

Angelson [47] argued that efforts to address the cause of deforestation were jumping between two main approaches: the population approach, which includes increasing food and energy needs and the market approaches, which include the growing global demand for commodity crops. Both play crucial roles in aggravating the extent of deforestation. Smallholder farmers are part of both approaches since they often face food and energy supply challenges and also the major producers of most commodity crops. Hence, smallholder farmers are the key stakeholders that need to be at the core of the discourse around the solutions to deforestation. Therefore, understanding smallholders' 
behaviour in their contexts [48] forms the core of the search for solutions to deforestation and forest degradation. In trying to understand the behavioral aspects of smallholder-driven D\&D, supported by two case studies, three broad categories of factors were identified - these are contextual, attitudinal, and habit or routine activities. In the two case study areas, we found that contextual factors are most crucial factors leading to D\&D. Hence, the discussion largely focuses on this set of factors which are further subdivided into necessity driven, market driven, policy and governance failure related. In MSF, Ethiopia, most of the underlying D\&D forces are necessity- and market driven by nature, while in MMF, Kenya, they are mostly policy- and governance-driven. In both case studies, farmers showed interest to conserve forests and are not depleting it intentionally, since they know forests are key sources of wood for energy and construction materials.

The first and the most relevant of the contextual factors is the D\&D driven by necessity or subsistence needs, e.g., clearance of land for agriculture and cutting trees for wood for energy and construction. Similar findings were also reported in Ghana whereby subsistence needs drive D\&D [49]. Angelsen [47] emphasized subsistence needs influenced by population growth as one of the key drivers of deforestation. Clearing of forest lands to gain more agricultural area emanated from the need to produce more to feed their growing families and also supply food to the market. Further, the perception that land clearing secures long-term claims to the land may lead to excessive forest clearance, often much larger than needed for cultivation. This is very much in line with Angelsen [47] who argued that clearing forest lands to increase land area possession is an investment decision and the drivers of such decisions have to be scrutinized carefully. The main reason why farmers overexploit forests is the absence of alternative sources of wood for energy and construction materials and the continuing land degradation affecting the food production potential. Such necessity-driven forest exploitation is rather easy to spot but complex to address as any measure to fulfil such needs should provide alternatives to the scarce wood source.

The second category of factors driving D\&D is market forces, i.e., increasing demands created from urban and peri-urban areas for charcoal wood, fuelwood, and construction wood. Leblois et al. [50] found out that agricultural trade is among the main factors aggravating deforestation in developing countries. D\&D attributed to market forces is not as straightforward to detect as the necessity-driven forces. For example, illegal timber and charcoal wood exploitation in both case studies result from the activities of close by farmers and illegal loggers from outside the forest landscape. The culprits of such activities often operate invisibly, hence posing serious challenges to address D\&D. They view the forest as an income generating opportunity and exploit it unsustainably to maximize revenues. Within the market forces, an emerging factor is the growing wood-based enterprises which are producing wooden furniture to sell to the growing population in the urban and peri-urban areas. The demand being created through this channel is largely driven by the booming middle class who often prefer locally produced furniture for cost reasons. This creates illegal artisanal logging which supplies wood to the small-scale sawmills around MSF.

The third set of factors driving D\&D include policy challenges and governance failure. D\&D due to governance failure links with both the necessity-driven and market-driven factors. Evictions of local communities, irregular land allocations limiting forest use rights, poor engagement and weak consultation of local communities in decision concerning the resources use and management were among the key governance factors that exacerbated illegal exploitation of forests by local communities. Such factors undermine the sense of ownership of forest resources by famers. Sometimes, land titles are granted by simply clearing and capturing forest or savannah land in many tropical areas. Unfortunately, this kind of process legitimizes the destruction of forests. This calls for a proper land use plan to guide what kind of land or land cover can be used for what purpose. Unless there is a clear structure or process at the policy level to guide this, it is difficult to put an end to the problem. Equally important is also the need for able institutions and institutional frameworks that could enforce the provisions and restrictions in the policy with regards to how land should be used. The need for a critical look at resource governance schemes to harmonize the needs and interests of local communities and their 
ambition to conserve forests were emphasized widely in the literature [44,51,52]. Besides revising the governance policies, addressing such governance failures requires engaging institutions and actors (particularly smallholder farmers) who play major roles in managing the forest.

A closer look at the factors also shows that except the necessity-driven factors, D\&D are largely aggravated by factors from outside the local area (Figure 3). This also calls for design of broader interventions to counter the problem than the current approach of emphasizing forest-agriculture transitions/frontiers only. For instance, looking only at the areas very close to the forests (Figure 3), subsistence needs are strongly relevant, but the actions of the smallholders are not only driven by subsistence needs. It is influenced also by the demand for products from outside and by the weak resource governance schemes applicable currently.

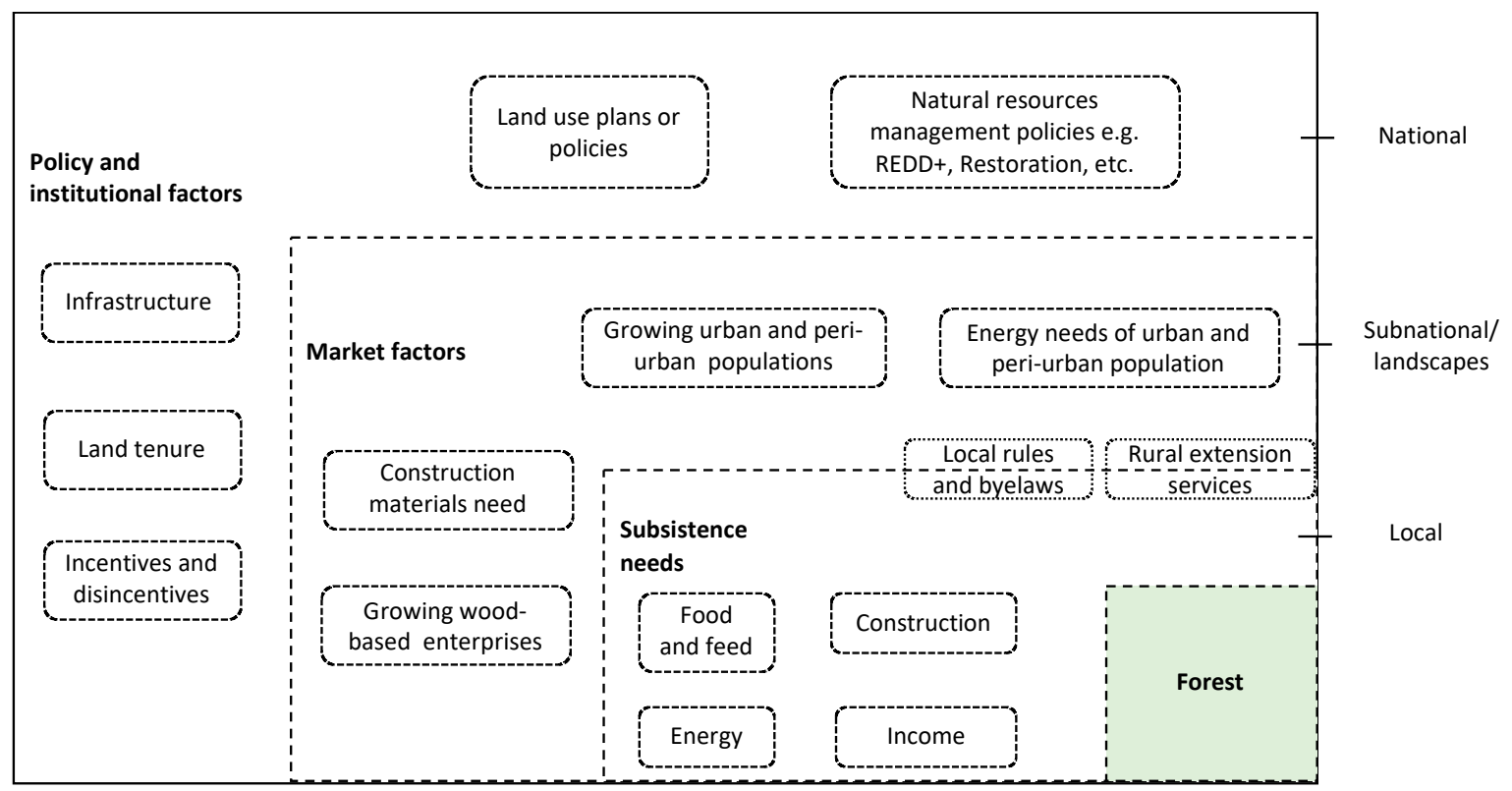

Figure 3. The relevant scale at which different drivers play strongly in influencing smallholder farmers decisions at local levels. Note: rural extension services and local rules and bylaws are relevant to both the subsistence needs and market forces.

\subsection{The Interdependence among the Key Factors and the Need for Systems Approach of Addressing Drivers}

From the results of the case study forests assessed, it is clear that addressing the factors behind smallholder-driven D\&D requires a much broader solutions framework that should rely on system's approach. This deviates quite significantly from the current efforts of dealing with D\&D which often is concentrated in the deforestation frontiers only. The three categories of contextual factors are interdependent and there are intricate connections between them all, which cumulatively aggravates forest exploitation. It is therefore impossible to address smallholder-driven D\&D without paying proper attention to each of the factors identified in this assessment. For instance, if there is no proper land use plan that guides how land is used in a given country, it is difficult to stop people from exploiting forests by converting it to farmlands to either feed their own families or sell it to the market to generate income. It is to be noted also that putting in place land use policy or plan alone may not solve the problem fully if there is no measure to cap or stabilize the growing urban and peri-urban population creating demand for wood products and food crops that are produced in rural areas. A long-term solution to the growing wood demand due to urbanization is to develop access to affordable, renewable energy sources to reduce the use of charcoal and firewood for cooking and heating. Putting in place appropriate incentive infrastructure helps in sustaining such transition, e.g., temporary energy subsidies. At the same time investment in improving agricultural land productivity should be a priority 
by providing access of farmers to inputs (e.g., adaptable varieties, agricultural credits, etc.) to improve farming practices.

Figure 4 demonstrates the complex interdependence among the specific drivers associated with the factors.

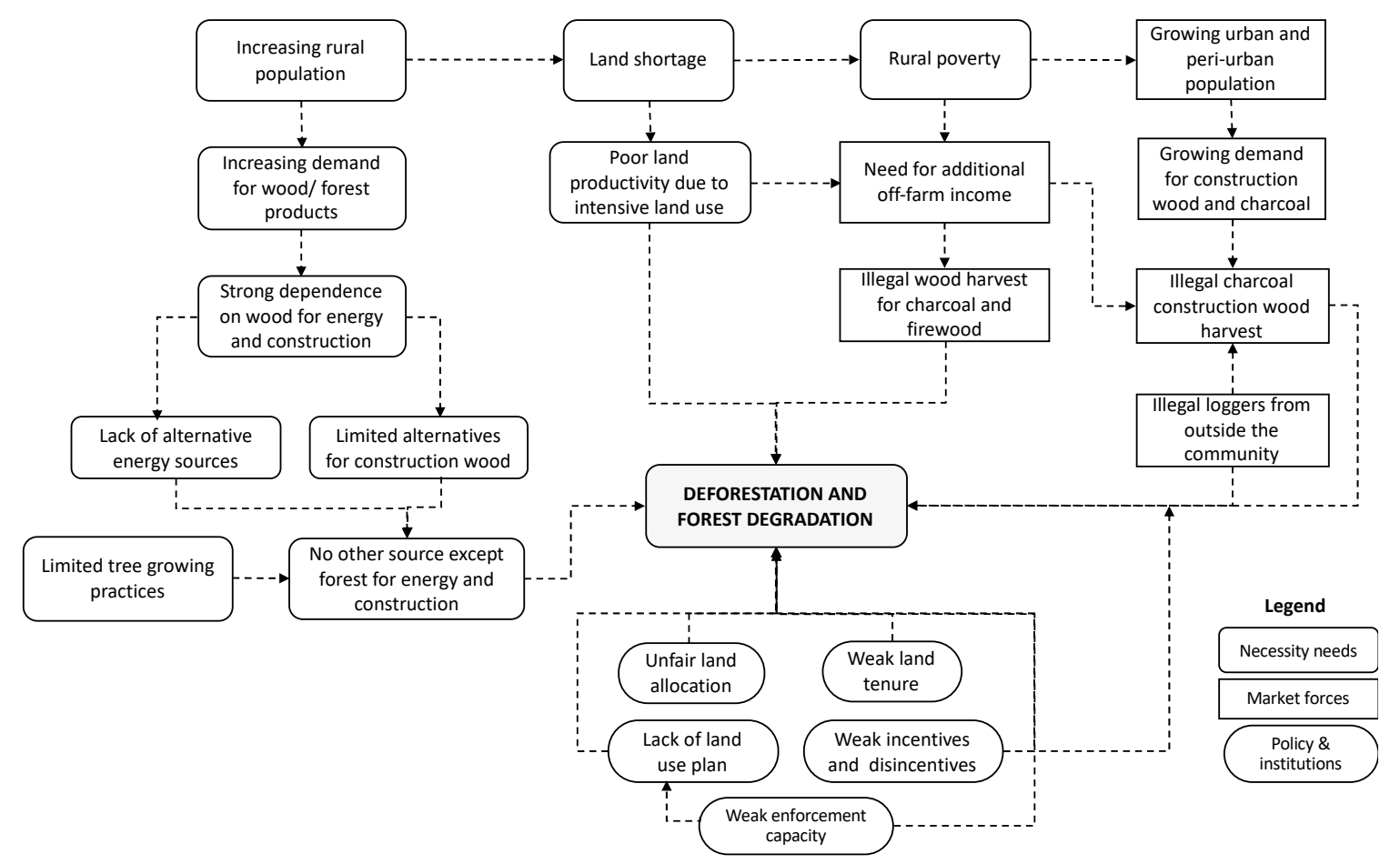

Figure 4. A schematic of processes leading to smallholder-driven D\&D at a local level. Note the crosscutting nature of the policies and governance issues.

The interdependence (Figure 4) and scale-based linkages (Figure 3) call for a systems approach to address smallholder D\&D. There is no one single solution to the problem but rather a composite of measures tackling the interdependent factors in the mix. Since the factors are broadly multisectoral, the need for a multisectoral approach to addressing smallholder-driven D\&D is undoubtedly among the best strategies. The use of incentive schemes should be planned and executed carefully so that by solving one problem we may not be aggravating another factor that promotes D\&D. For instance, if we are to meet the income needs of farmers by improving farming techniques, it could on the other hand ignite land clearing for more farmland to get additional income. Under such contexts, rules and regulations need to be in place to guide the extent to which a certain measure can be applied. Local institutions and bylaws could play crucial role in controlling such matters. Another aspect of providing various incentives is that it may create activity displacement, which in effect moves for example the D\&D activities from one forest to the other. Therefore, it is important that the design process of measures or incentives to tackle smallholder-driven D\&D should specifically take a system's approach. Once the system attributes are defined (based on the drivers aggravating D\&D), it is relatively easier to identify leveraging points and the corresponding actions that may be feasible and effective [10]. Duguma et al. [53], in a study assessing the factors for the success of community forests in Cameroon, identified a number of intervention areas which could act as leveraging points, e.g., benefit generation, technical support, financial support, etc. Effective forest management models could actually help minimize the extent of the key factors at the local level at least and hence motivating communities to conserve the forest. Effective and efficient incentives and disincentives (taxation, penalties, etc.) play a crucial role in helping the process of adoption of the potential measures [54] while also understanding the tradeoffs associated with the measures and the incentives. 


\section{Way Forward: Towards a Response Strategy for Reducing Smallholder-Driven D\&D}

Among the principles for addressing environmentally destructive behavior is to look at the problem from the actors' perspectives and engage them in the search for solutions [21]. The case studies used here revealed that the search for solutions often was confined to repression, i.e., limiting the access and use rights of the smallholder farmers and sometimes ignoring them in the management of the forests. However, this did not help in alleviating the problem because factors aggravating the destructive behavior (i.e., D\&D) were in some cases beyond the control of the local communities (see Figure 4), e.g., pressure from urban and peri-urban population and lack of access to nonwood alternatives. There exist two principal strategies to address environmentally destructive behaviors such as D\&D: structural strategies and informational strategies.

Potential structural strategies. Several structural strategies could be employed in forests under similar management regime of the two considered as case study sites. Table 2 lays out selected structural strategies that can be used to influence the existing context so that the extent and impacts of those factors aggravating D\&D could be minimized.

Table 2. Structural strategies that may be used to address factors aggravating D\&D.

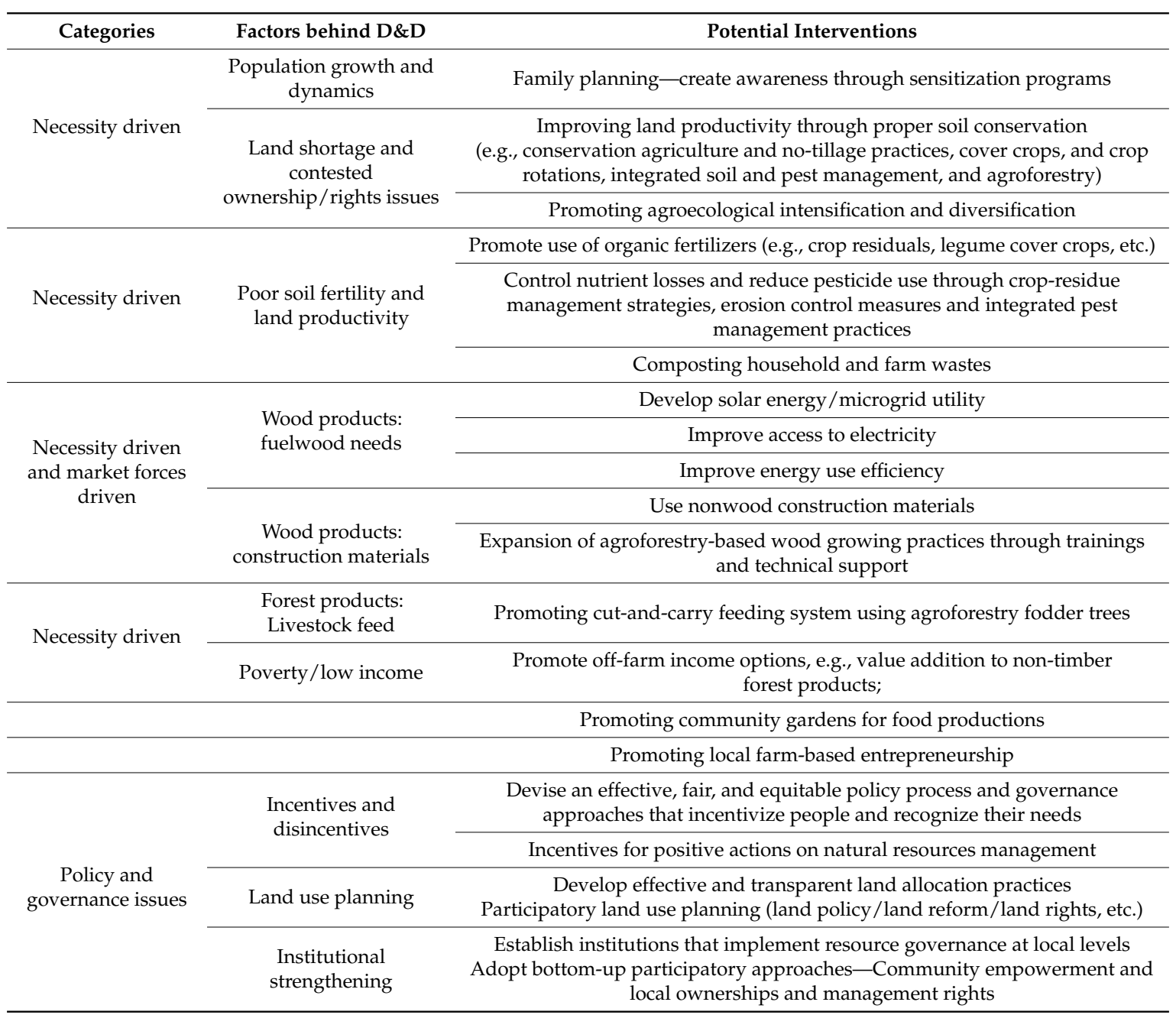

Informational strategies. Informational strategies represent the means of complementing structural strategies by addressing factors associated with attitudes, habits, and routine actions. This may involve training, awareness creation, creating mechanisms of exposure to efficient technologies through workshops, and consultation sessions and availing information that is required to change the way they do their routine activities that affect forests. Despite the injustices in the past, local 
communities should realize that the collective benefits of forests outweigh the benefits generated from cutting them down. Hence, they should be keen to safeguard the forests. When the level of awareness of benefits from forests increases, the sense of cooperation among the community to protect and reduce the extent of D\&D particularly due to external forces could be improved. Rustagi et al. [55] found that groups that cooperate have higher quality of forest as compared to those marred with free-rider problems who often link up with the external forces invisibly damaging the forest. Informational strategies promote prosocial norms and behaviors that improve collective management of available resources as also argued by Rustagi et al. [55].

Informational strategies should also be directed to other stakeholders such as forest managers who in the past underestimated the action of local communities. Forest managers need to understand that local communities can also be part of the solution and should be fully included in forest management. Local communities also have valuable indigenous/local/traditional knowledge that should be adopted and deployed for the common benefit of forest protection. This collective awareness and better understanding of stakeholders' range of interests and actions could lead to enhanced synergistic actions toward minimizing D\&D in the context of smallholder farmers (see Hull et al. [56]). With improved collaboration or cooperation among stakeholders (local communities, forest managers, local authorities, etc.), destructive behaviors and actions could be minimized as the weak links used by illegal loggers and other free riders might be exposed. With improved collaboration, communities increase monitoring frequency [55] thus helping to detect any illegal intrusions and exploitations. Those who benefit more from the resources should invest more time in monitoring the forest. Strengthening such intercommunity and inter-actors' networks improves collaboration and hence reduces illegal exploitation [57].

Implementing both structural and informational strategies require addressing the key barriers for the promotion of positive environmental behaviors. As argued by Gardner and Stern [58], the degree to which individuals or communities take pro-environmental actions depends on the nature of barriers to take the actions in terms of time and resources the actions require. Considering the state of capacity of the communities in the two case study forests, the need for incentives is crucial to enable communities take positive actions. Some of the barriers (e.g., related to policies and institutional issues) could be addressed by crafting rules and regulations and empowering local institutions that enforce the policy provisions. Overall, there is a need for relevant and effective incentives and disincentives that should be deployed at scale to promote positive actions.

This study used two case studies as the basis to highlight the need to address smallholder D\&D as an environmental behavior and discuss the potential options. Further research is still needed to find the impact magnitudes of each of the factors and the extent to which changes in behavior could be achieved. Based on our assessment, we conclude that smallholder-driven D\&D is the result of complex set of factors and actors that are either clearly notable or operating from the background. Hence, addressing smallholder-driven D\&D requires taking into account the following measures.

- Strategies to address D\&D should consider the interests and livelihood needs of the forest dependent people and the surrounding communities;

- Dealing with D\&D requires understanding the context, particularly the strong interconnections between socioeconomic attributes and forest resources management ambitions. This has to be at the core of intervention designs to promote forest management.

- Policy measures, responses, and interventions to address D\&D should capture the complex set of actors rather than focusing only on the smallholder farmers;

- Embrace a system's approach to capture the multisectoral and multiscale features of the factors aggravating smallholder-driven D\&D could be more effective.

- Supporting communities to take positive actions to forest management requires addressing both structural barriers, i.e., capacity, resource limitations, etc. and policy barriers through designs of appropriate incentives and disincentives. 
These options collectively or individually help modify or change behavior for the benefit of forests and the ecosystems services they provide and even achieve REDD+ objectives.

Author Contributions: Conceptualization, L.A.D. and J.A.; Methodology, L.A.D., P.A.M., and J.A.; Formal Analysis, L.A.D., J.A., A.N.A, and B.G.; Writing-L.A.D., J.A., A.N.A, B.G., F.B., and J.M.N.; Visualization, L.A.D.; Funding Acquisition, P.A.M.

Funding: This research was funded by CGIAR FTA Programme (Forests, Trees, and Agroforestry).

Conflicts of Interest: The authors declare no conflicts of interest. The funders had no role in the design of the study; in the collection, analyses, or interpretation of data; in the writing of the manuscript, or in the decision to publish the results.

\section{References}

1. Lawson, S.; Blundell, A.; Cabarle, B.; Basik, N.; Jenkins, M.; Canby, K. Consumer Goods and Deforestation: An Analysis of the Extent and Nature of Illegality in Forest Conversion for Agriculture and Timber Plantations; Forest Trend Report Series: Washington, DC, USA, 2014.

2. United Nations (UN). United Nations Millennium Declarations; A/RES/55; UN General Assembly: New York, NY, USA, 2000. Available online: http://www.un.org/millennium/declaration/ares552e.pdf (accessed on 13 October 2016).

3. Convention on Biological Diversity. Conference of the Parties Decision X/2: Strategic Plan for Biodiversity 2011-2020. 2011. Available online: www.cbd.int/decision/cop/?id=12268 (accessed on 27 October 2016).

4. United Nations Framework Convention on Climate Change (UNFCCC). Decision 2/CP. 13: Reducing Emissions from Deforestation in Developing Countries: Approaches to Stimulate Action; United Nations Framework Convention on Climate Change: Bonn, Germany, 2007. Available online: http:/ / unfccc.int/resource/docs/ 2007/cop13/eng/06a01.pdf (accessed on 19 September 2016).

5. Intergovernmental Panel on Climate Change (IPCC). Climate Change 2007: Mitigation of Climate Change. Contribution of Working Group III to the Fourth Assessment Report of the Intergovernmental Panel on Climate Change; Cambridge University Press: Cambridge, UK, 2007.

6. Van der Werf, G.R.; Morton, D.C.; DeFries, R.S.; Olivier, R.S.; Kasibhatla, P.S.; Jackson, R.B.; Randerson, J.T. $\mathrm{CO}_{2}$ emissions from forest loss. Nat. Geosci. 2009, 2, 737-738. [CrossRef]

7. Stern, N. The Economics of Climate Change: The Stern Review; Cambridge University Press: Cambridge, UK, 2006.

8. Angelsen, A. (Ed.) Moving Ahead with REDD: Issues, Options and Implications; Centre for International Forestry Research: Bogor, Indonesia, 2008; 172p.

9. United Nations (UN). Report of the United Nations Conference on Sustainable Development Rio de Janeiro: UN: A/CONF.216/16. 2012. Available online: http:/ / www.uncsd2012.org/content/documents / 814UNCSD\%20REPORT\%20final\%20revs.pdf (accessed on 26 July 2016).

10. Duguma, L.A.; Minang, P.A. Leveraging landscapes: A systems approach to drivers of change. In Climate-Smart Landscapes: Multifunctionality in Practice; Minang, P.A., van Noordwijk, M., Freeman, O.E., Mbow, C., de Leeuw, J., Catacutan, D., Eds.; ASB Partnership for The Tropical Forest margins, World Agroforestry Centre: Nairobi, Kenya, 2015; pp. 135-149.

11. Intergovernmental Panel on Climate Change (IPCC). Land Use, Land-Use Change and Forestry; Cambridge University Press: Cambridge, UK, 2000.

12. UN-REDD. Framework Document Collaborative Program on Reducing Emissions from Deforestation and Forest Degradation in Developing Countries (UN-REDD), Technical Series, UN-REDD Program. 2008. Available online: http:/ / www.un-redd.org/ (accessed on 13 October 2016).

13. Somorin, O.A. Climate impacts, forest-dependent rural livelihoods and adaptation strategies in Africa: A review. Afr. J. Environ. Sci. Technol. 2010, 4, 903-912.

14. Hashmiu, I. Carbon Offsets and Agricultural Livelihoods: Lessons Learned from a Carbon Credit Project in the Transition Zone of Ghana; STEPS Working Paper 50; STEPS Centre: Brighton, UK, 2012.

15. Dzingirai, V. Rural disenfranchisement through carbon: The case of Kariba REDD, Zimbabwe. In Carbon Conflicts and Forest Landscapes in Africa; Scoones, I., Leach, M., Eds.; Routledge: London, UK, 2014.

16. Eastaugh, C. Climate Change Impacts on African Forests and People; IUFRO Occasional Paper No. 24; International Union of Forest Research Organizations (IUFRO): Vienna, Austria, 2010; ISSN 1024-414X. 
17. Weiner, B. Reflections and reviews-Attributional thoughts about consumer behavior. J. Consum. Res. 2000, 27, 382-387. [CrossRef]

18. Weiner, B. An Attributional Theory of Motivation and Emotion; Springer: New York, NY, USA, 1986.

19. Winkler, I. Contemporary Leadership Theories; Springer: New York, NY, USA, 2010.

20. Steg, L.; Vlek, C. Encouraging pro-environmental behavior: An integrative review and research agenda. J. Environ. Psychol. 2009, 29, 309-317. [CrossRef]

21. Stern, P. Toward a coherent theory of environmentally significant behavior. J. Soc. Issues 2000, 56, 407-424. [CrossRef]

22. Eisenhardt, K.M. Building theories from case study research. Acad. Manag. Rev. 1989, 14, 532-550. [CrossRef]

23. Rowley, J. Using case studies in research. Manag. Res. News 2002, 25, 16-27. [CrossRef]

24. Angelsen, A.; Kaimowitz, D. Rethinking the causes of deforestation: Lessons from economic models. World Bank Res. Obs. 1999, 14, 73-98. [CrossRef]

25. Rudel, T.K.; Defries, R.; Asner, G.P.; Laurance, W.F. Changing drivers of deforestation and new opportunities for conservation. Conserv. Biol. 2009, 23, 1396-1405. [CrossRef]

26. Geist, H.J.; Lambin, E.F. Proximate Causes and Underlying Driving Forces of Tropical Deforestation. BioScience 2002, 52, 143-150. [CrossRef]

27. Duguma, L.A.; Hager, H.; Gruber, M. The community-state forest interaction in Menagesha Suba area, Ethiopia: the challenges and possible solutions. For. Trees Livelihoods 2009, 19, 111-128. [CrossRef]

28. Nkako, F.M.; Lambrechts, C.; Gachanja, M.; Woodley, B. Maasai Mau Forest Status Report of 2005; Ewaso Ngiro South Development Authority: Narok, Kenya, 2005.

29. Central Statistical Agency of Ethiopia. Population Projection of Ethiopia for All Regions at Weredalevel from 2014-2017. 2013. Available online: http:/ / www.csa.gov.et/index.php/ehioinfo-internal?download=724: population-projection-of-ethiopia-for-all-regions-atwereda-level-from-2014-2017\&start=5 (accessed on 1 March 2017).

30. Feyissa, A.K.; Suryabhagavanand, K.V.; Satishkumar, B. Assessment of Habitat Changes in Holeta Watershed, Central Oromia, Ethiopia. Int. J. Earth Sci. Eng. 2014, 7, 1370-1375.

31. Central Statistical Agency of Ethiopia. Population Statistics Abstract 2012. Available online: http://www. csa.gov.et/images/documents/pdf_files/nationalstatisticsabstract/2011/2011\%20population.pdf (accessed on 1 March 2016).

32. Duguma, L.A.; Hager, H. Consumption and species preference for house construction wood in central highlands of Ethiopia-Implications for enhancing tree growing. J. For. Res. 2010, 21, 104-110. [CrossRef]

33. DeFries, R.S.; Rudel, T.; Uriarte, M.; Hansen, M. Deforestation driven by urban population growth and agricultural trade in the twenty-first century. Nat. Geosci. 2010, 3, 178-181. [CrossRef]

34. Dercon, S.; Hoddinott, J.; Woldehanna, T. Shocks and consumption in 15 Ethiopian villages, $1999-2004$. J. Afr. Econ. 2005, 14, 559-585. [CrossRef]

35. Duguma, L.A.; Minang, P.A.; Freeman, O.E.; Hager, H. System wide impacts of fuel usage patterns in the Ethiopian highlands: Potentials for breaking the negative reinforcing feedback cycles. Energy Sustain. Dev. 2014, 20, 77-85. [CrossRef]

36. Atela, J.O.; Denich, M.; Kaguamba, R.; Kibwage, J. Agricultural land allocation in small farms around MSF, Kenya and the implications on carbon stocks. J. Ecol. Nat. Environ. 2012, 4, 98-108.

37. NEMA (National Environmental Management Authority). Mau at a Glance; National Environmental Management Authority: Nairobi, Kenya, 2013; 40p.

38. Government of Kenya. The 1979 National Population and Household Census; Government Printer: Nairobi, Kenya, 1979.

39. Government of Kenya. The 2009 National Population and Household Census; Government Printer: Nairobi, Kenya, 2009.

40. Government of Kenya. Narok District Environmental Action Plan, 2009-2013. 2009. Available online: www. nema.go.ke (accessed on 2 April 2015).

41. Republic of Kenya. Kenya Forestry Master Plan, 1995-2020: Executive Summary; Ministry of Environment and Natural Resources, Government Printer: Nairobi, Kenya, 1994.

42. Ndungu Land Commission. Report of the Commission of Inquiry into the Irregular Allocation of Public Land; Government Printer: Nairobi, Kenya, 2004. 
43. Wass, P. Kenya's Indigenous Forests: Status, Management, and Conservation; Island Press: Washington, DC, USA, 1995.

44. Ayana, A.N.; Vandenabeele, N.; Arts, B. Performance of participatory forest management in Ethiopia: institutional arrangement versus local practices. Crit. Policy Stud. 2015, 11, 19-38. [CrossRef]

45. Republic of Kenya. Forests Act, 2005; Government Printer: Nairobi, Kenya, 2005.

46. Republic of Kenya. Participatory Forest Management Guidelines; Government Printer: Nairobi, Kenya, 2007.

47. Angelsen, A. Agricultural expansion and deforestation: Modelling the impact of population, market forces and property rights. J. Dev. Econ. 1999, 58, 185-218. [CrossRef]

48. Pratihast, A.K.; Herold, M.; De Sy, V.; Murdiyarso, D.; Skutsch, M. Linking community-based and national REDD+ monitoring: A review of the potential. Carbon Manag. 2013, 4, 91-104. [CrossRef]

49. Appiah, M.; Blay, D.; Damnyag, L.; Dwomoh, F.K.; Pappinen, A.; Luukkanen, O. Dependence on forest resources and tropical deforestation in Ghana. Environ. Dev. Sustain. 2009, 11, 471-487. [CrossRef]

50. Leblois, A.; Damette, O.; Wolfersberger, J. What has driven deforestation in developing countries since the 2000s? Evidence from new remote-sensing data. World Dev. 2017, 92, 82-102. [CrossRef]

51. Agrawal, A. Forests, governance, and sustainability: Common property theory and its contributions. Int. J. Commons 2007, 1, 111-136. [CrossRef]

52. Rigg, J. Forests and farmers, land and livelihoods, changing resource realities in Thailand. Glob. Ecol. Biogeogr. Lett. 1993, 3, 277-289. [CrossRef]

53. Duguma, L.; Minang, P.; Foundjem-Tita, D.; Makui, P.; Piabuo, S. Prioritizing enablers for effective community forestry in Cameroon. Ecol. Soc. 2018, 23. [CrossRef]

54. Minang, P.A. Values, Incentives and Ecosystem Services in Environmentalism. In Rethinking Environmentalism: Linking Justice, Sustainability, and Diversity; Strüngmann Forum Reports; Lele, S., Brondizio, E.S., Byrne, J., Mace, G.M., Martinez-Alier, J., Eds.; MIT Press: Cambridge, MA, USA, 2018; Volume 23.

55. Rustagi, D.; Engel, S.; Kosfeld, M. Conditional cooperation and costly monitoring explain success in forest commons management. Science 2010, 330, 961-965. [CrossRef]

56. Hull, R.B.; Kimmel, C.; Robertson, D. Innovating solutions to deforestation: cross-sector collaboration in the Amazon. J. Entrepreneurship Organ. Manag. 2016, 5, 172. [CrossRef]

57. Agrawal, A.; Nepstad, D.; Chhatre, A. Reducing emissions from deforestation and forest degradation. Annu. Rev. Environ. Resour. 2011, 36, 373-396. [CrossRef]

58. Gardner, G.T.; Stern, P.C. Environmental Problems and Human Behavior; Pearson Custom Publishing: Boston, MA, USA, 2002.

(C) 2019 by the authors. Licensee MDPI, Basel, Switzerland. This article is an open access article distributed under the terms and conditions of the Creative Commons Attribution (CC BY) license (http://creativecommons.org/licenses/by/4.0/). 